\title{
Important Woody Plant Species, their Management and Conservation Status in Balawoli Sub-county, Uganda
}

\author{
John R.S. Tabuti
}

\section{Research}

\begin{abstract}
Woody plant species are threatened in Uganda. To conserve these species there is need to generate information that may be used to design management plans. This study was conducted in Balawoli Sub-county, Kamuli District, Uganda between July 2009 and January 2010. We addressed four questions: (1) which woody species are most preferred? (2) what is the conservation status of these species and for which species have changes in local availability been observed? (3) what management practices exist for woody species? and (4) what tenure rights exist for woody plants? Data were generated through guided questionnaire interviews. Seventeen species are valued most within the community. These species are multipurpose and altogether have 25 different uses for the community. The most frequently harvested products are edible fruits, firewood and timber. The value of these species as a source of income is low. Milicia excelsa (Welw.) C.C. Berg, Albizia coriaria Welw. ex Oliv., Combretum molle R. Br. ex G. Don, Terminalia glaucescens Planch. ex Benth., Coffea spp., Combretum collinum Fresen. and Citrus spp. are becoming scarce. However, Artocarpus heterophyllus Lam., Mangifera indica L., Ficus natalensis Hochst., Citrus sinensis (L.) Osbeck, Acacia sp., Senna siamea (Lam.) H.S. Irwin \& Barneby, Eucalyptus spp., Pinus spp., Carica papaya L. and Lantana camara $\mathrm{L}$. are increasing in abundance. The main factors leading to the scarcity of some species include over-harvesting, destructive harvesting, pests, poor planting of trees by farmers, and droughts. The key factors contributing to some species' success are that the species are: planted, drought resistant, regenerate naturally, easy to manage, mature fast, available as seedlings. Farmers maintain 51 woody species that they plant or retain when found growing naturally on their land. Some farmers are constrained in planting trees by lack of seedlings, pest infestations, drought and lack of land. Species are managed in crop
\end{abstract}

fields, the courtyard and home garden. Men own trees in the homestead, are more involved in tree management and selling of tree products, than women.

\section{Introduction}

Woody species, i.e., trees and shrubs, are threatened in many different parts of the world (Augusseau et al. 2006). It is estimated that $10 \%$ of all tree species are threatened (Williams 1998). The highest rates of woody species loss are in the tropics (FAO 2009). Estimates suggest that in Uganda $0.9-3.15 \%$ of the forested area disappears every year and that the forested areas have shrunk from 52 to $24 \%$, in the last 100 years (NEMA 2002, UNDP 2007). The major causes of woody species loss are linked to rapid human population growth rates and poverty (Jha \& Bawa 2006, FAO 2009). These drivers force people to harvest woody species using poor methods and at unsustainably high intensities; to expand crop agriculture into woody species habitats; and to shorten fallows that are

\section{Correspondence}

John R.S. Tabuti, Makerere University, College of Agricultural and Environmental Sciences (MUCAES), Kampala, UGANDA. jtabuti@muienr.mak.ac.ug, jtabuti@gmail.com

Ethnobotany Research \& Applications 10:269-286 (2012)

Published: July 15, 2012 
necessary for woody species reestablishment (Augusseau et al. 2006, Baillie et al. 2004).

Rural and marginalized households are highly dependent on woody plants for their subsistence and income generation (Marshall \& Newton 2003, Shackleton et al. 2001). For instance, in Uganda, more than $90 \%$ of the homesteads use wood fuels (NEMA 2002). The loss of woody plants that supply products that are important for local subsistence or income generation can, therefore, cause untold suffering among people who have traditionally relied on them to satisfy their needs (Primack 1998, Shackleton et al. 2001, Walter 2001). This is especially true for women (Marshall \& Newton 2003, Upadhyay 2005). Across Africa, women care for their families and are responsible for gathering firewood for cooking. Firewood scarcities are likely to increase their burden at a time when men are increasingly emigrating to towns and transferring their activities, such as small ruminant herding, to women (Djoudi \& Brockhaus 2011, Kiptot \& Franzel 2011)

To safeguard livelihoods and reduce poverty among communities that are dependent on naturally growing plants, it is important that the species they depend on are sustainably managed. For woody species to be effectively managed and conserved, farmers must be involved because of two reasons. First, over $70 \%$ of woody species, including tree resources, are on private land owned by farmers (NEMA 2002). Second, decisions regarding which species are selected for maintenance (or destruction) are made by farmers at the household level basing on how much a household will benefit from growing a particular species and how such a species fits in the household's labor and input requirement (e.g., land) (Dalle \& Potvin 2004 , Simons \& Leakey 2004, Warner 1994). For this collaboration with farmers to contribute successfully to species conservation and planting, there must be a clear understanding of which species are highly valued by farmers (Warner 1994). The identification of species preferred by individual households is decisive to tree and other woody species management because farmers will only invest in such species, if the selected trees provide them with clear benefits.

However, there are woody species that are threatened but which must be managed by the state or the local governments. These include: 1) species valued by farmers, but for which farmers lack the essential skills and capital resources to manage; 2 ) species that are important to only a small section of the community, e.g., medicinal plants; and 3) species not highly preferred by farmers but which must be conserved to maintain ecosystem services such as flood control (Chan et al. 2006, Díaz et al. 2006).

The aim of this study was to generate information that would contribute to the design of robust management plans for the conservation, and increase, of woody species cover in Uganda by conducting a case study in Bala- woli Sub-county. The study was guided by the following key questions:

1. Which species are most preferred in Balawoli Subcounty?

2. What is the conservation status of woody plant species and for which species have changes in local availability been observed?

3. What management practices exist for woody species in the landscape? and,

4. What tenure rights exist for trees?

\section{Methods}

Fieldwork for this study was conducted in Balawoli Subcounty, of Bugabula County in Kamuli District. Balawoli Sub-county is about $200 \mathrm{~km}$ from Kampala, the capital city of Uganda, and is located between $32^{\circ} 93^{\prime}-33^{\circ} 15^{\prime} \mathrm{E}$ and $2^{\circ} 81^{\prime}-3^{\circ} 04^{\prime} \mathrm{N}$ (Figure 1), at an altitude of $1060 \mathrm{~m}$ above sea level. This study was conducted between July 2009 and January 2010 using ethnobotanical techniques described in the next paragraph. Respondents were selected using a multi-stage sampling procedure based on the local administrative units. The local administrative units in Uganda, from highest to lowest are county, sub-county, parish and village. Balawoli sub-county was randomly selected from the eight sub-counties of Bugabula County. In turn, four parishes were randomly selected from Balawoli sub-county (Figure 1). From each parish, four villages were again randomly selected, to make a total of 12 villages (Bugaya, Bugaga, Bandali, Buganza Bunampogo, Bukayibaale, Bukitimbo, Bulinda, Bulumaga buteila, Butoigo Bulwile, Buwaiswa, Nabitalo A. and Nambale). In every village, we generated a list of all inhabitants to use as a sampling frame, with the help of the local area politician (Local Council I, Chairperson). From this list 20 households were selected for inclusion in the interviews. We interviewed 238 people; of whom 133 were male. All respondents were paid a token fee at the end of the interview as compensation for their time.

A guided questionnaire was used in face-to-face interviews. The interviews were designed to determine what the most preferred woody species were and which species people were selling. They also investigated the existing tree management practices, constraints people faced when managing trees, which opportunities existed for tree management, and who owned trees in the homestead. Lastly, respondents were requested to list species that were becoming locally scarce, those that were becoming more abundant and what factors had contributed to these changes. Demographic data were collected for all respondents. Direct observations were made on issues relevant to the study objectives, such as destructive harvesting of trees and vegetation types. Plant species were identified in the field. Voucher specimens of these species were collected and deposited in Makerere University Herbarium (MHU). 


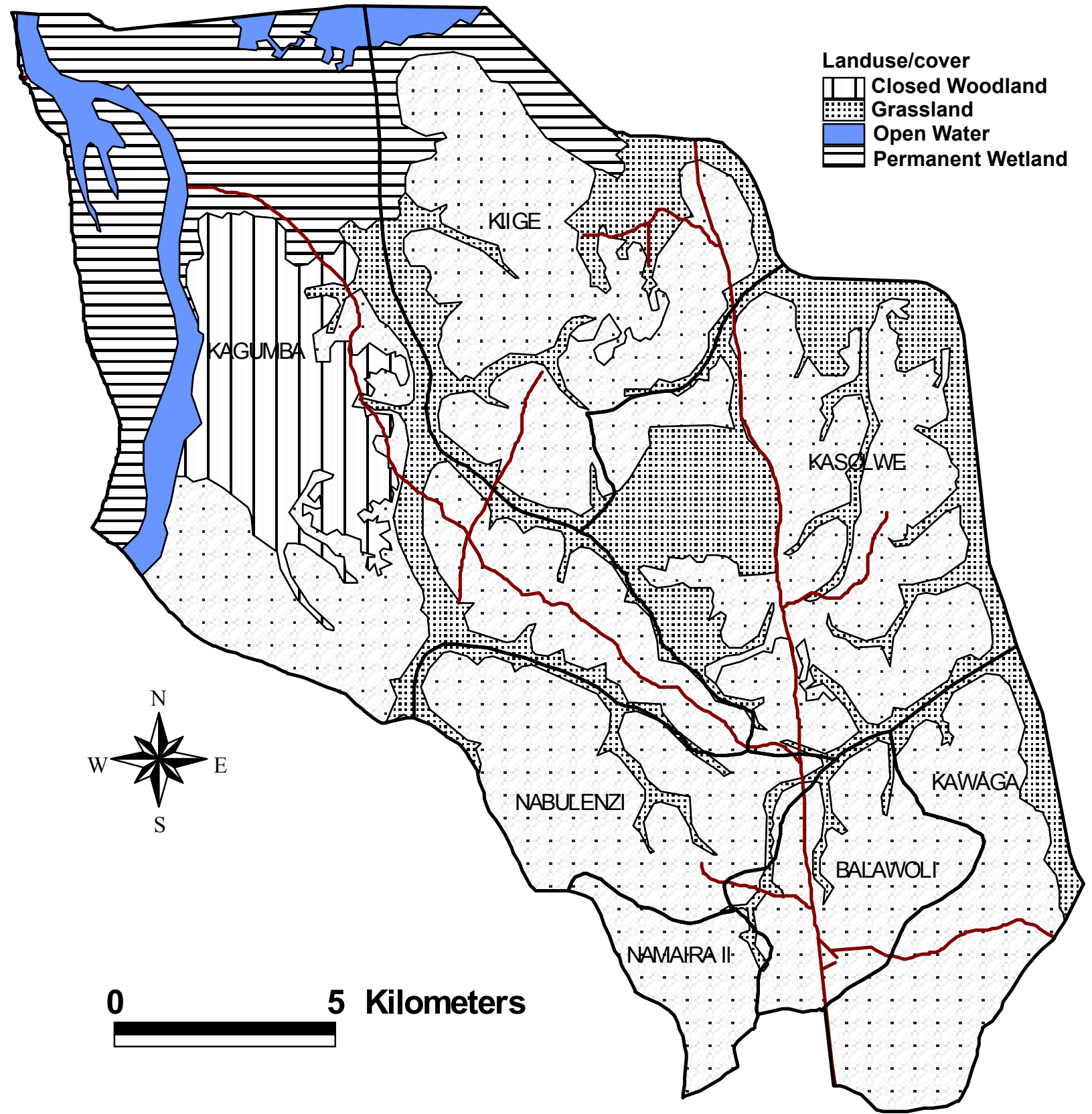

Figure 1. Balawoli Sub-county, Kamuli District, Uganda showing the land use types and parishes. Research was conducted in Balawoli, Kagumba, Kibuye and Namaira Parishes.

All survey data were entered in Microsoft Office Excel spreadsheets, checked for errors, and edited before coding and importing into SPSS version 12 (SPSS 2003) for analysis. Frequencies and percentages were generated by SPSS and presented in tables or figures.

\section{Results}

\section{Biographic details}

The respondents had an average age of 39 years (range $16-93)$. The majority of the respondents had attained only primary level of formal education (equivalent to 7 years or less) (Table 1). The main source of livelihood for the respondents was crop farming. Other respondents were engaged in livelihood activities such as retail trade. The respondents were mostly Christian by religion and $\mathrm{Ba}-$ soga by tribe and belonged to male-headed households. Most of them owned the land that they farmed (94.1\%) with close to $65 \%$ owning $\leq$ two hectares of land (Table 2 ). 
Table 1. Respondents' biographic details in Balawoli Subcounty, Kamuli District, Uganda.

\begin{tabular}{|c|c|c|c|}
\hline Attribute & $\%$ & Attribute & $\%$ \\
\hline \multicolumn{2}{|l|}{ Education } & \multicolumn{2}{|l|}{ Tribe } \\
\hline None & 22.6 & Musoga & 71.3 \\
\hline Primary & 58.4 & Mukenye & 11.0 \\
\hline Secondary & 17.7 & Munyoro & 5.9 \\
\hline Tertiary & 0.9 & Atesot & 5.5 \\
\hline $\begin{array}{l}\text { Adult } \\
\text { education }\end{array}$ & 0.4 & Muganda & 3.4 \\
\hline \multirow{2}{*}{\multicolumn{2}{|c|}{ Household head occupation }} & Musamya & 0.8 \\
\hline & & Mutooro & 0.8 \\
\hline Farming & 68.8 & Luo & 0.4 \\
\hline Retail trade & 8.9 & Mugwere & 0.4 \\
\hline Fishing & 6.3 & Munyara & 0.4 \\
\hline $\begin{array}{l}\text { Teaching in } \\
\text { local school }\end{array}$ & 2.1 & \multirow{2}{*}{\multicolumn{2}{|c|}{ Religion }} \\
\hline $\begin{array}{l}\text { Cycle } \\
\text { transporter }\end{array}$ & 1.7 & & \\
\hline $\begin{array}{l}\text { Other artisanal } \\
\text { activities }\end{array}$ & 12.2 & Protestant & 38.0 \\
\hline \multirow{2}{*}{\multicolumn{2}{|c|}{ Household head's sex }} & Catholic & 37.6 \\
\hline & & Moslem & 13.2 \\
\hline Male & 91.6 & Adventist & 6.0 \\
\hline Female & 8.4 & Pentecostal & 3.8 \\
\hline & & Traditionalist & 1.3 \\
\hline
\end{tabular}

Table 2. Estimated farm size holding by farmers in Balawoli Sub-county, Kamuli District, Uganda.

\begin{tabular}{|l|r|}
\hline Estimate of farm area & $\%$ \\
\hline very small (<0.4 ha) & 15.5 \\
\hline small $(0.4-0.9$ ha) & 28.4 \\
\hline intermediate (1 - 2 ha) & 20.6 \\
\hline large (larger than 2 ha) & 23.2 \\
\hline very large (larger than 15 ha) & 12.3 \\
\hline
\end{tabular}

\section{Priority woody species of Balawoli Sub-county}

Sixty-nine species were valued within the community (Appendix 1). Seventeen of these were mentioned more frequently (by more than $30 \%$ of the respondents), and were therefore considered as the most important (Table 3 ). These priority species were multipurpose, commonly having more than three uses. Taken altogether, these species had 25 different values for the community. The most frequently harvested products from the woody species were edible fruits, firewood and timber (Figure 2, Table 3 ). These products were used in the home for subsistence or were infrequently sold to earn cash incomes (Table 4). The people also valued the provision of shade by trees. The value of these species as a source of income was rarely mentioned (only $4 \%$ of the respondents), although $49 \%$ of the respondents claimed to have sold some woody products.

Table 3. Priority woody species of Balawoli Sub-county, Kamuli District, Uganda. Products shown are based on species mentioned by respondents asked about useful species, those who claimed to have sold products and those intending to plant the species in the future. A main product is considered to be that mentioned by at least $50 \%$ of the people or the most frequently mentioned use for the species. Only products mentioned by 2 or more people are included here.

\begin{tabular}{|c|c|c|c|c|c|}
\hline \multirow[t]{2}{*}{ Species } & \multicolumn{2}{|l|}{ Products } & \multicolumn{3}{|c|}{ Proportion (\%) of respondents: } \\
\hline & Main & Other & $\begin{array}{l}\text { mentioning } \\
\text { preference } \\
\text { for species }\end{array}$ & $\begin{array}{c}\text { claiming to } \\
\text { have sold } \\
\text { product }\end{array}$ & $\begin{array}{l}\text { wishing to } \\
\text { plant this } \\
\text { species }\end{array}$ \\
\hline Mangifera indica L. & $\begin{array}{l}\text { Edible fruit, } \\
\text { Firewood }\end{array}$ & $\begin{array}{l}\text { Medicine, shade, } \\
\text { income, charcoal }\end{array}$ & 99 & 14.3 & 9.5 \\
\hline Maesopsis eminii Engl. & $\begin{array}{l}\text { Timber, } \\
\text { firewood }\end{array}$ & $\begin{array}{l}\text { Income, poles, shade, } \\
\text { soil fertility, medicine }\end{array}$ & 84 & 4.6 & 21.2 \\
\hline Artocarpus heterophyllus Lam. & Edible fruit & Firewood, timber, shade & 83 & 17.2 & 4.7 \\
\hline $\begin{array}{l}\text { Citrus sinensis (L.) } \\
\text { Osbeck }\end{array}$ & Edible fruit & Firewood, income & 72 & 21.0 & 10.3 \\
\hline $\begin{array}{l}\text { Milicia excelsa (Welw.) } \\
\text { C.C. Berg }\end{array}$ & Timber & $\begin{array}{l}\text { Firewood, charcoal, } \\
\text { construction, shade, rain } \\
\text { formation, medicine }\end{array}$ & 87 & 7.1 & 4.7 \\
\hline Ficus natalensis Hochst. & Shade & $\begin{array}{l}\text { Bark cloth, fodder, } \\
\text { firewood, timber, } \\
\text { Edible fruit, poles, } \\
\text { charcoal, windbreaker }\end{array}$ & 68 & 1.7 & 3.0 \\
\hline Coffea spp. & Income & Edible fruit & 32 & 10.9 & 5.2 \\
\hline
\end{tabular}


Tabuti - Important Woody Plant Species, their Management and Conservation 273 Status in Balawoli Sub-county, Uganda

\begin{tabular}{|c|c|c|c|c|c|}
\hline \multirow[t]{2}{*}{ Species } & \multicolumn{2}{|l|}{ Products } & \multicolumn{3}{|c|}{ Proportion (\%) of respondents: } \\
\hline & Main & Other & $\begin{array}{l}\text { mentioning } \\
\text { preference } \\
\text { for species }\end{array}$ & $\begin{array}{c}\text { claiming to } \\
\text { have sold } \\
\text { product }\end{array}$ & $\begin{array}{l}\text { wishing to } \\
\text { plant this } \\
\text { species }\end{array}$ \\
\hline Eucalyptus spp. & Timber & $\begin{array}{l}\text { Poles, firewood, income, } \\
\text { medicine, windbreaker }\end{array}$ & 34 & 1.3 & 8.4 \\
\hline Albizia coriaria Welw. ex Oliv. & Timber & $\begin{array}{l}\text { Firewood, charcoal, } \\
\text { Construction, Medicine }\end{array}$ & 43 & & 0.5 \\
\hline Pinus spp. & Timber & $\begin{array}{l}\text { Income, firewood, } \\
\text { Edible fruit }\end{array}$ & 25 & & 16 \\
\hline Persea americana Mill. & Edible fruit & Firewood, medicine & 32 & 3.8 & 2.3 \\
\hline Carica papaya L. & Edible fruit & & 31 & 2.1 & 0.7 \\
\hline Ficus sycomorus L. & Shade & $\begin{array}{l}\text { Timber, firewood, } \\
\text { charcoal, intercropping, } \\
\text { construction, } \\
\text { windbreaker } \\
\end{array}$ & 26 & & 0.2 \\
\hline $\begin{array}{l}\text { Senna siamea (Lam.) H.S. Irwin } \\
\text { \& Barneby }\end{array}$ & Firewood & $\begin{array}{l}\text { Shade, poles, timber, } \\
\text { beautify compound }\end{array}$ & 23 & & 1.6 \\
\hline $\begin{array}{l}\text { Markhamia lutea (Benth.) } \\
\text { K. Schum. }\end{array}$ & Poles & Firewood, timber, shade & 21 & 1.7 & 0.7 \\
\hline Citrus reticulata Blanco & Edible fruit & Medicine & 16 & 4.6 & 1.6 \\
\hline Citrus limon (L.) Osbeck & Edible fruit & $\begin{array}{l}\text { Medicine, firewood, } \\
\text { timber, income }\end{array}$ & 17 & 3.4 & 0.9 \\
\hline
\end{tabular}

\section{Marketing of tree products}

$49 \%$ of the respondents claimed they sold products from 24 woody species in local markets (Appendix 2). Table

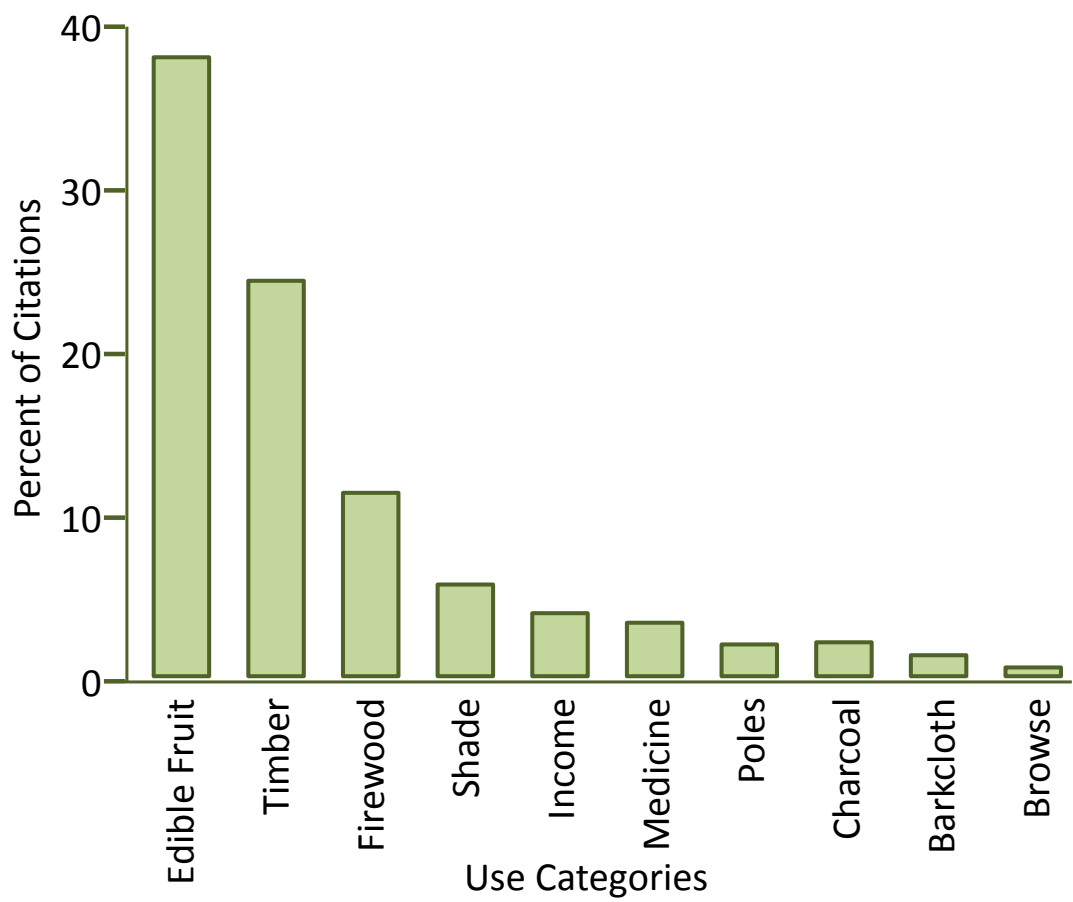

Figure 2. Major uses of woody species in Balawoli Sub-county, Kamuli District, Uganda. Only uses cited by more than $1 \%$ of the respondents are shown.
4 shows the most frequently mentioned species (cited by 9 or more people). Edible fruits from these species were sold once or twice a year, and timber infrequently. The products were sold to fellow villagers or to traders.

A few respondents also mentioned processed products such as furniture, timber, and firewood. All family members are involved in selling of products, but husbands dominate in the activity (Table 5).

\section{Species conservation statuses}

Respondents were asked to list species they thought were declining in availability and those they thought were increasing. For the same species, there were respondents who thought that the species was declining, while other respondents thought otherwise. For every species, the frequencies for increase were compared with those for decrease and the greater of the two frequencies taken as the status for the species. For example, Milicia excelsa (Welw.) C.C. Berg was perceived to be declining by $86 \%$ of the respondents and to be increasing by $14 \%$ (Table 6 ). From this 
Table 4. Commonly sold tree products, clients and frequency of selling tree products in Balawoli Sub-county, Kamuli District, Uganda. All species shown, apart from M. excelsa and M. eminii, yield edible fruits

\begin{tabular}{|c|c|c|c|c|c|c|}
\hline \multirow[t]{2}{*}{ Species } & \multirow[t]{2}{*}{ Middlemen } & \multirow{2}{*}{$\begin{array}{l}\text { Fellow } \\
\text { farmers }\end{array}$} & \multirow[t]{2}{*}{ Total } & \multirow[t]{2}{*}{$\%$} & \multicolumn{2}{|c|}{ Frequency of selling } \\
\hline & & & & & Infrequent & 1-2X/year \\
\hline $\begin{array}{l}\text { Citrus sinensis (L.) } \\
\text { Osbeck }\end{array}$ & 44 & 6 & 50 & 19.6 & & $X$ \\
\hline Artocarpus heterophyllus Lam. & 28 & 13 & 41 & 16.1 & & $X$ \\
\hline Mangifera indica $\mathrm{L}$. & 28 & 6 & 34 & 13.3 & & $x$ \\
\hline Coffea spp. & 24 & 1 & 25 & 9.8 & & $x$ \\
\hline Milicia excelsa (Welw.) C.C. Berg & 7 & 9 & 16 & 6.3 & $\mathrm{X}$ & \\
\hline Citrus reticulata Blanco & 11 & & 11 & 4.3 & & $x$ \\
\hline Maesopsis eminii Engl. & 4 & 6 & 10 & 3.9 & $\mathrm{X}$ & \\
\hline Persea americana Mill. & 7 & 2 & 9 & 3.5 & & $x$ \\
\hline
\end{tabular}

Table 5. Person responsible for selling woody products in the family in Balawoli Sub-county, Kamuli District, Uganda. [Only male-headed households selling tree products are considered $(n=132)$. There were also 8 female-headed households involved in selling tree products.]

\begin{tabular}{|l|c|r|}
\hline Responsible family member & Frequency & $\%$ \\
\hline Husband only & 79 & 59.9 \\
\hline Husband and wife & 37 & 28.0 \\
\hline Wife only & 12 & 9.1 \\
\hline All family members & 2 & 1.5 \\
\hline Wife and children & 2 & 1.5 \\
\hline
\end{tabular}

comparison, the interpretation was that the perception is of a species declining. From this analysis (Table 6) six species are decreasing while 15 are increasing.

The key factors believed by respondents to be leading to species disappearance include destructive harvesting to produce charcoal, firewood, timber and poles; attack by pests; low propagation of trees; and droughts (Table 7). On the other hand, the species known to be increasing in abundance are successful because they are planted, are drought resistant, regenerate naturally, are easy to manage, mature fast, and their seedlings are available among other factors (Table 8).

Table 6. Respondents perception of woody species status in Balawoli Sub-county, Kamuli District, Uganda. Species status is taken to be the greater of the two frequencies. Species with fewer than 2 citations are excluded. Species with few citations are not included because it is difficult to determine status from such a low number of citations.

\begin{tabular}{|c|c|c|c|}
\hline \multirow[t]{2}{*}{ Species } & \multicolumn{2}{|c|}{$\begin{array}{l}\text { Frequency of respondents } \\
\text { claiming the species is: }\end{array}$} & \multirow[t]{2}{*}{$\begin{array}{l}\text { Species } \\
\text { status }\end{array}$} \\
\hline & decreasing & increasing & \\
\hline Milicia excelsa (Welw.) C.C. Berg & 86 & 14 & Decreasing \\
\hline Albizia coriaria Welw. ex Oliv. & 59 & 7 & Decreasing \\
\hline Combretum molle R. Br. ex G. Don & 30 & 7 & Decreasing \\
\hline Terminalia glaucescens Planch. ex Benth. & 22 & 2 & Decreasing \\
\hline Maesopsis eminii Engl. & 19 & 92 & Increasing \\
\hline Ficus natalensis Hochst. & 16 & 48 & Increasing \\
\hline Citrus sinensis (L.) Osbeck & 11 & 19 & Increasing \\
\hline Coffea spp. & 9 & 6 & Increasing \\
\hline Combretum collinum Fresen. & 9 & 5 & Decreasing \\
\hline Eucalyptus spp. & 7 & 18 & Increasing \\
\hline Citrus reticulata Blanco & 6 & 2 & Decreasing \\
\hline Mangifera indica L. & 6 & 52 & Increasing \\
\hline Artocarpus heterophyllus Lam. & 4 & 56 & Increasing \\
\hline Ficus glumosa Delile & 4 & 3 & \\
\hline Vepris nobilis (Delile) Mziray & 4 & 3 & \\
\hline
\end{tabular}


Tabuti - Important Woody Plant Species, their Management and Conservation 275 Status in Balawoli Sub-county, Uganda

\begin{tabular}{|l|c|c|c|}
\hline Carica papaya L. & 4 & 10 & Increasing \\
\hline Acacia spp. (mawa) & 3 & 8 & Increasing \\
\hline Acacia polyacantha Willd. & 2 & 19 & Increasing \\
\hline Ficus sycomorus L. & 2 & 4 & \\
\hline Lannea schweinfurthii (Engl.) Engl. & 2 & 3 & \\
\hline Citrus limon (L.) Osbeck & 2 & & \\
\hline Persea americana Mill. & 2 & & \\
\hline Albizia zygia (DC.) J.F. Macbr. & 3 & & \\
\hline Vitex ferruginea Schumach. \& Thonn. & 2 & & \\
\hline Senna siamea (Lam.) H.S. Irwin \& Barneby & & 19 & Increasing \\
\hline Pinus spp. & & 16 & Increasing \\
\hline Lantana camara L. & & 10 & Increasing \\
\hline Senna spectabilis (DC.) H.S. Irwin \& Barneby & & 6 & Increasing \\
\hline Markhamia lutea (Benth.) K. Schum. & & 4 & Increasing \\
\hline Thevetia peruviana (Pers.) K. Schum. & & 2 & \\
\hline
\end{tabular}

Table 7. Factors reported by respondents in Balawoli Sub-county, Kamuli District, Uganda to be contributing to woody species decreasing availability.

\begin{tabular}{|l|r|}
\hline Factor & Frequency \\
\hline Charcoal burning & 129 \\
\hline Harvested for timber & 94 \\
\hline Pests & 34 \\
\hline Harvested for wood to make canoes & 17 \\
\hline Not planted & 13 \\
\hline Drought & 6 \\
\hline Poles & 5 \\
\hline Firewood & 5 \\
\hline High demand for products & 3 \\
\hline Not drought resistant & 3 \\
\hline Little benefit & 2 \\
\hline Drain soils & 2 \\
\hline Felled by winds & 1 \\
\hline Easily dries up & 1 \\
\hline Is a habitat for caterpillars & 1 \\
\hline Dries up easily & 1 \\
\hline Long period to maturity & 2 \\
\hline No seeds and seedling & 1 \\
\hline Not productive enough & 3 \\
\hline Crop farming & 3 \\
\hline Require a lot of care to grow & 1 \\
\hline & 1 \\
\hline
\end{tabular}

\section{Local tree management practices}

Farmers stated that they were maintaining 51 trees species on their lands (Appendix 3). The farmers also said
Table 8. Factors reported by respondents in Balawoli Sub-county, Kamuli District, Uganda to be contributing to woody species increasing availability

\begin{tabular}{|l|r|}
\hline Factor & Frequency \\
\hline Planted because it is useful & 203 \\
\hline Seedlings or other propagules available & 34 \\
\hline Drought resistant & 32 \\
\hline Regenerates naturally & 31 \\
\hline Easy to manage & 28 \\
\hline Matures fast & 26 \\
\hline Produce much seed & 21 \\
\hline Wind dispersed & 19 \\
\hline Not harvested for charcoal & 17 \\
\hline Dispersed by birds & 14 \\
\hline Promotion by government & 6 \\
\hline Has market & 5 \\
\hline Pest resistant & 5 \\
\hline Not destructively harvested & 4 \\
\hline Grows in swamps & 1 \\
\hline Protected by thorns & 1 \\
\hline Government restricts exploitation & 1 \\
\hline Weed & \\
\hline
\end{tabular}

that they wanted to add more species on their farms (Table 3). Species were managed mostly in crop fields, courtyards, and home garden. Within the family, men were more involved in tree management (54\%) compared to their wives $36.2 \%$ (Table 9). Tree species were either planted or retained by protecting wildings found growing naturally on farmers' land. Farmers themselves commonly propagated seedlings. Additional tree husbandry 
Table 9. Tree management practices in Balawoli Subcounty, Kamuli District, Uganda.

\begin{tabular}{|c|c|c|c|}
\hline \multirow{2}{*}{\multicolumn{2}{|c|}{\begin{tabular}{|l|c|} 
Factor & $\%$ \\
Person responsible for \\
tree management
\end{tabular}}} & \multirow{2}{*}{\multicolumn{2}{|c|}{\begin{tabular}{l|l|} 
Factor & $\%$ \\
$\begin{array}{l}\text { Source of woody species } \\
\text { seedlings }\end{array}$
\end{tabular}}} \\
\hline & & & \\
\hline Husband & 54 & Prepared by self & 58.7 \\
\hline Wife & 36.2 & From neighbour & 22.2 \\
\hline Children & 8.5 & $\begin{array}{l}\text { Bought from } \\
\text { nursery }\end{array}$ & 14.7 \\
\hline Laborer & 1.4 & $\begin{array}{l}\text { From } \\
\text { neighbourhood }\end{array}$ & 2.9 \\
\hline \multirow{2}{*}{\multicolumn{2}{|c|}{ Tree tenure }} & $\begin{array}{l}\text { National } \\
\text { Agricultural } \\
\text { Advisory Servic- } \\
\text { es (NAADS) }\end{array}$ & 0.6 \\
\hline & & $\begin{array}{l}\text { From IRID } \\
\text { (N.G.O) }\end{array}$ & 0.4 \\
\hline Husband only & 79.5 & $\begin{array}{l}\text { Distributed } \\
\text { by LC5 }\end{array}$ & 0.2 \\
\hline $\begin{array}{l}\text { Husband and } \\
\text { wife }\end{array}$ & 10.2 & $\begin{array}{l}\text { National Forestry } \\
\text { Authority (NFA) }\end{array}$ & 0.2 \\
\hline $\begin{array}{l}\text { All family mem- } \\
\text { bers }\end{array}$ & 7.9 & $\begin{array}{l}\text { Uganda National } \\
\text { Farmers' Associ- } \\
\text { ation (UNAFA) }\end{array}$ & 0.2 \\
\hline Wife only & 2.3 & \multirow{2}{*}{\multicolumn{2}{|c|}{ Niche }} \\
\hline \multirow{2}{*}{\multicolumn{2}{|c|}{$\begin{array}{l}\text { Propagation material for } \\
\text { woody species }\end{array}$}} & & \\
\hline & & Garden & 64.8 \\
\hline Seed & 82.1 & Courtyard & 19.3 \\
\hline Wildings & 10 & Homegarden & 12.8 \\
\hline Cuttings & 7.9 & Hedge & 2.9 \\
\hline & & Everywhere & 0.3 \\
\hline
\end{tabular}

practices include protection of trees against damage and pruning to encourage sprouting. Trees, according to most respondents, belonged to the husband in the home. Farmers shared freely some of the products from trees (mostly edible fruits, firewood, medicines and wildings).

The most frequently mentioned and therefore main challenges faced by farmers were lack of seedlings, attacks by pests, drought and lack of land. Many farmers' suggested that improving access to water could mitigate the challenges to tree planting. In particular efforts should be made to introduce irrigation. They also suggested that there should be endeavors to control pests, and that tree nurseries should be created in, or close to their sub-county.

Farmers rarely sought advice or encouragement regarding tree management, but when they did the media (radio), village meetings and political leaders are important sources of this information (Table 10).
Table 10. Source of information regarding tree planting in Balawoli Sub-county, Kamuli District, Uganda.

\begin{tabular}{|l|r|}
\hline Source of information & $\%$ \\
\hline Radio & 52.4 \\
\hline Local political leaders & 25.6 \\
\hline Neighbors Advisory Services & 6.9 \\
\hline $\begin{array}{l}\text { National Agricultural program } \\
\text { (NAADS) }\end{array}$ \\
\hline Self help projects & 2.8 \\
\hline Seminars & 1.6 \\
\hline Books & 0.8 \\
\hline Extension workers & 0.8 \\
\hline National Forestry Authority (NFA) officials & 0.8 \\
\hline Kamuli nursery centre & 0.4 \\
\hline Ministry campaigns & 0.4 \\
\hline $\begin{array}{l}\text { National Environment Management Authority } \\
\text { (NEMA) }\end{array}$ & 0.4 \\
\hline $\begin{array}{l}\text { Uganda National Farmers' Association (UN- } \\
\text { AFA) }\end{array}$ & 0.4 \\
\hline Traditional knowledge & 0.4 \\
\hline Action aid (NGO) & 0.4 \\
\hline Husband & 0.4 \\
\hline Television & 0.4 \\
\hline
\end{tabular}

\section{Discussion}

This study identified 17 most highly-valued and priority woody species. These species were either the most frequently mentioned, were sometimes sold, or people planned to add them to those already on their farms. The species were valued by the people of Balawoli for the same reason people in other areas of the developing world value such species, that is, they provide products valuable for peoples' subsistence, especially edible fruits, firewood and timber. The role of these species as a source of income was not very important. This is not surprising because few gathered products are traded in markets and it is usually marginalized people that trade in species for which well established markets do not exist (Shackleton et al. 2001, Styger et al. 1999). A few farmers mentioned ecosystem services from woody species, such as improving soil fertility.

Some of the priority species are known to be disappearing. The direct factors of destructive harvesting practices and over-harvesting, known by respondents to cause declines in species availability as well as the other underlying factors, that drive over-exploitation or deter widespread tree management (Table 7), are not unique to Balawoli and are quite widespread (Augusseau et al. 2006, FAO 2009, UNDP 2007). Some species were however increasing in availability according to local per- 


\section{Tabuti - Important Woody Plant Species, their Management and Conservation 277 Status in Balawoli Sub-county, Uganda}

ceptions. This study generated a useful checklist of desirable characteristics that make woody species desirable to farmers, which should be considered when deciding on which trees to promote with farmers. These include economic, biological (e.g., fast maturity), and ecological factors (e.g., drought resistance, early maturing) (Table 8).

To improve woody species conservation in Balawoli, concerned stakeholders, e.g., National Agricultural Advisory Services, should focus on the 17 most important species identified. Farmers are more likely to collaborate meaningfully in planting trees that have a clear benefit for them (Allen 1990, Kahurananga et al. 1993, Warner 1994). Species that are lowly valued may not be readily managed or planted by farmers and for such species the local government and other stakeholders need to take the lead.

The people of Balawoli are interested in, and are maintaining trees on their land because the trees have important values. Men dominate in all aspects of tree management; it is mostly men who plant and own trees, and sell tree products. It is not clear how tenurial arrangements at the homestead level affect tree growing in Balawoli. It is probable that women participate less in tree growing because of tenurial right issues or because they are more involved in more labor intensive regular work of planting food crops and managing the home. According to some authors, men's ownership of trees and the land on which trees grow may act as a disincentive for women to plant trees (Obonyo et al. 2008). On the other hand there are those who believe that tree tenure does not affect tree planting decisions at the homestead level.

\section{Conclusion and recommendations}

Farmers in Balawoli Sub-county value most highly 17 woody species. These species play significant roles in subsistence well being. The key products harvested from the species are edible fruit, firewood, timber and poles. Species are also valued for the provision of shade. Farmers maintain many woody species around the homestead. However, the survival status of some woody species is poor.

Efforts by extension workers and others interested in maintaining trees on farm should focus on the 17 priority species identified here. The key threats identified here; poor markets for tree products, destructive harvesting for timber and wood for construction, and charcoal making should be addressed to improve tree cover. In addition, the advantageous factors identified in the community such as willingness to plant trees should be enhanced. One specific and pragmatic action to stimulate tree planting should be to increase the motivation of farmers to plant trees by promoting and creating markets for tree products. Improvement of markets or creation of markets will call for investigations into value chains of selected species/ products. Other issues that need attention are: identifying solutions to control insect pests, and improvements in access to water and to planting material. Regarding the improvement to planting materials, research should be undertaken to improve our understanding of the germination and seedling establishment behavior of the priority species by conducting investigations both in experimental gardens and on farms.

The tenurial rights of trees, whereby men own and manage trees, observed in this study may have an influence on tree planting. It is not clear whether the low involvement by women is affecting tree planting and management in the sub-county and this needs investigation.

The collaboration of farmers in tree planting is likely to lead to increased availability of the priority species without increasing woody species diversity. The protection of woody species diversity, therefore, remains the responsibility of the local administration. The local administration should undertake among other actions the reforestation of its district reserves and undertake tree planting on public lands such as road reserves.

Lastly, this study has been conducted in eastern Uganda, but the loss of woody plants is occurring all over Uganda. It is necessary to have this study replicated in different agro-ecological regions of Uganda in order to capture the entire diversity of priority woody species for the country.

\section{Acknowledgment}

This study was funded by the International Foundation for Science (IFS) grant No. S/4644-1. Makerere University provided additional support. Permission to conduct the study was granted by the Uganda National Council for Science and Technology (UNCST), permission No. NS 236. The people of Balawoli are acknowledged with gratitude for collaborating in this study. Collins Kukunda, Alexander Mbiiro and lan Bandese assisted with data collection. We also thank the anonymous referees of this manuscript for their useful comments.

\section{Literature Cited}

Allen, J.A. 1990. Homestead tree planting in two rural Swazi communities. Agroforestry Systems 11:11-22.

Augusseau, X., P. Nikiéma \& E. Torquebiau. 2006. Tree biodiversity, land dynamics and farmers' strategies on the agricultural frontier of southwestern Burkina Faso. Biodiversity and Conservation 15:613-630.

Baillie, J.E.M., C. Hilton-Taylor \& S.N. Stuart. 2004. Editors of 2004 IUCN Red List of Threatened Species. A Global Species Assessment. International Union for Conservation of Nature, Gland, Switzerland. 
Chan, K.M.A., M.R. Shaw, D.R. Cameron, E.C. Underwood \& G.C. Daily. 2006. Conservation planning for ecosystem services. PLoS Biology 4(11):e379.

Dalle, S.P. \& C. Potvin. 2004. Conservation of useful plants: An evaluation of local priorities from indigenous communities in Eastern Panama. Economic Botany 58:38-57.

Díaz, S., J. Fargione, F. Stuart Chapin III \& D. Tilman. 2006. Biodiversity loss threatens human well-being. PLoS Biology 4(8):e277.

Djoudi, H. \& M. Brockhaus. 2011. Is adaptation to climate change gender neutral? Lessons from communities dependent on livestock and forests in Northern Mali. International Forestry Review 13:123-135.

FAO. 2009. State of the World's Forests 2009. Food and Agriculture Organization of the United Nations, Rome.

Jha, S. \& K.S. Bawa. 2006. Population growth, human development, and deforestation in biodiversity hotspots. Conservation Biology 6:906-912.

Kahurananga, J., Y. Alemayehu, S. Tadesse \& T. Bekele. 1993. Informal surveys to assess social forestry at Dibandiba and Aleto Wendo, Ethiopia. Agroforestry Systems 24:57-80.

Kiptot, E.\& S. Franzel. 2011. Gender and Agroforestry in Africa: Are women participating? World Agroforestry Centre, Nairobi.

Marshall, E. \& A.C. Newton. 2003. Non-timber forest products in the community of El Terrero, Sierra De Manantlán Biosphere Reserve, Mexico: Is their use sustainable? Economic Botany 57:262-278.

NEMA. 2002. State of the Environment Report for Uganda. National Environment Management Authority, Kampala.

Obonyo, E., J. Mogoi, V. Oeba \& P. Ongugo. 2008. Exclusion, poverty and inequality in decentralized Kenyan Forests: Bridging the divide. Pp. 14-17 in Proceedings of the 12th Biennial Conference of the International Association for the Study of Commons. Governing Shared Resources: Connecting Local Experience to Global Challenges. University of Gloucestershire, Cheltenham, England July 14-18.

Primack, R.B. 1998. Essentials of Conservation Biology. Sinauer Associates, Sunderland, Massachusetts.

Shackleton, S.E., C.M. Shackleton, T.R. Netshiluvhi, B.S. Geach, A. Ballance \& D.K. Fairbanks. 2001. Use patterns and value of savanna resources in three rural villages in South Africa. Economic Botany 56:130-146.

Simons, A.J. \& R.R.B. Leakey. 2004. Tree domestication in tropical agroforestry. Agroforestry Systems 61:167-181.

SPSS. 2003. SPSS version 12. SPSS Inc., Chicago, IIlinois.

Styger, E., J.E.M. Rakotoarimanana, R. Rabevohitra \& E.C.M. Fernandes. 1999 Indigenous fruit trees of Madagascar: potential components of agroforestry systems to improve human nutrition and restore biological diversity. Agroforestry Systems 46:289-310.

UNDP. 2007. Uganda Human Development Report: Rediscovering agriculture for human development. United Nations Development Programme, Kampala, Uganda.

Upadhyay, B. 2005. Women and natural resource management: Illustrations from India and Nepal. Natural Resources Forum 29:224-232.

Walter, S. 2001. Non-Wood Forest Products in Africa: A regional and national review. Working Paper FOPW/01/1. Food and Agriculture Organization of the United Nations, Rome.

Warner, K. 1994. Selecting Tree Species on the Basis of Community Needs. Food and Agriculture Organization of the United Nations, Rome.

Williams, N. 1998. Study finds $10 \%$ of tree species under threat. Science 281:1426. 
Tabuti - Important Woody Plant Species, their Management and Conservation 279 Status in Balawoli Sub-county, Uganda

\begin{tabular}{|c|c|c|c|c|c|c|c|c|c|c|c|c|c|c|c|c|}
\hline ๑ & $\begin{array}{l}\hat{\infty} \\
\infty \\
\infty\end{array}$ & $\begin{array}{l}0 \\
\stackrel{0}{0} \\
\infty\end{array}$ & 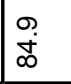 & $\begin{array}{l}\infty \\
\stackrel{\infty}{i} \\
\infty\end{array}$ & 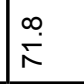 & $\begin{array}{l}0 \\
\infty \\
0\end{array}$ & $\begin{array}{l}m \\
\stackrel{m}{q}\end{array}$ & $\begin{array}{l}0 \\
\dot{m} \\
\tilde{m}\end{array}$ & $\frac{\stackrel{\rho}{m}}{\dot{m}}$ & 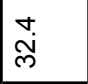 & $\check{m}$ & 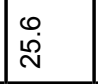 & 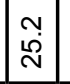 & $\check{\stackrel{\sim}{~}}$ & $\stackrel{\circ}{\grave{N}}$ & 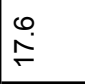 \\
\hline Total & $\stackrel{\sim}{\sim}$ & $\hat{N}$ & ָั & के & $\bar{\Sigma}$ & $\ddot{0}$ & ஜ뭉 & $\infty$ & $\stackrel{0}{r}$ & 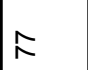 & $\sqrt{4}$ & $\overline{0}$ & 8 & 占 & in & ซ \\
\hline Demarcating land & & & & & & & & & & & & & & & & \\
\hline Mosquito repellant & & & & & & & - & & & & & & & & & \\
\hline Making soap & & & & & & & & & & & & & & & & \\
\hline Bee keeping & & & & & & & & & & & & & & - & & \\
\hline Water retention & & - & & & & & & & & & & - & & & & \\
\hline Fencing & & & - & & & & & & & & & & & & & \\
\hline Soil fertility & & & $m$ & & & & & & & & & & & & & \\
\hline Rubber & & & - & & & & & - & & & & & & & - & \\
\hline Rain formation & - & t & & & & - & - & - & & & & & & & & \\
\hline Beautify compound & & & & & & & & & & & & & - & $m$ & & \\
\hline Intercropping & & & - & & & $\wedge$ & & & & & & $m$ & & & & \\
\hline Wind breaker & & - & - & & & $m$ & & $\sim$ & & & & $\sim$ & - & - & - & \\
\hline Construction & & 0 & v & & & & $m$ & & & & & $\sim$ & & & & \\
\hline Charcoal & N & $r$ & & - & & $m$ & $\Lambda$ & & & & & $\theta$ & & $r$ & - & \\
\hline Poles & & - & $\infty$ & & & $\sim$ & - & 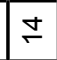 & & & & & & $\Lambda$ & $\infty$ & \\
\hline Medicine & t & N & n & & & & $\theta$ & $m$ & & $\sim$ & & & - & - & - & 10 \\
\hline Fodder & & & & & & ลิ & & & & & & & & & - & \\
\hline Bark cloth & & & - & & & ले & & & & & & & & & & \\
\hline Income & $m$ & - & 10 & - & N & & & 10 & $\overline{5}$ & & & & 우 & & & - \\
\hline Shade & $m$ & $\infty$ & $m$ & N & & กิ & - & - & & & & กิ & & $\infty$ & $m$ & \\
\hline Firewood & $\stackrel{2}{\circ}$ & $\div$ & 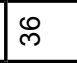 & $\infty$ & $m$ & N & $\ddot{r}$ & $m$ & & L & & $m$ & 0 & N & $m$ & $N$ \\
\hline Timber & - & ֻู & 운 & $m$ & & $\infty$ & R & 우 & & & & $\because$ & ৪) & 0 & $ㅇ$ & - \\
\hline Edible fruit & \& & - & - & $\underset{\infty}{\infty}$ & 8 & $m$ & - & & مֵ & 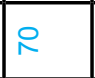 & 迹 & & $\sim$ & - & - & $\mathbb{N}$ \\
\hline 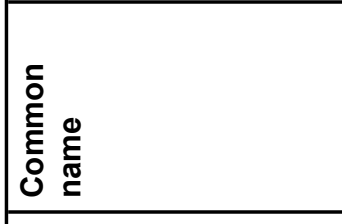 & 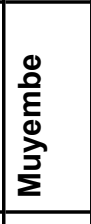 & $\frac{0}{5}$ & $\mid \begin{array}{l}\bar{N} \\
\bar{N} \\
\bar{N}\end{array}$ & 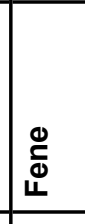 & 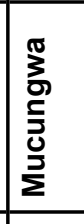 & 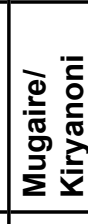 & $\frac{\pi}{\frac{\pi}{0}}$ & 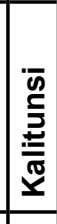 & 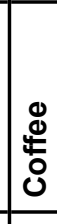 & 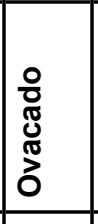 & $\begin{array}{l}\overline{\bar{\pi}} \\
\frac{0}{\pi} \\
0 \\
0\end{array}$ & 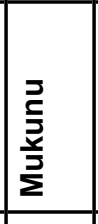 & 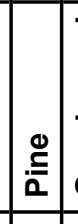 & 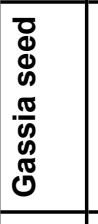 & 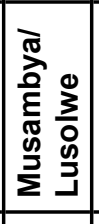 & 㢺 \\
\hline 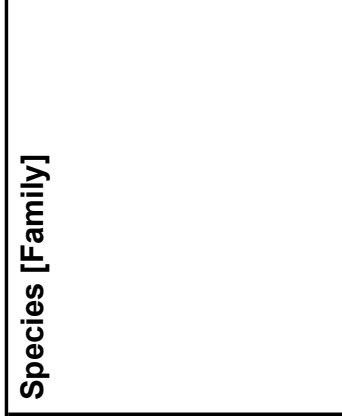 & 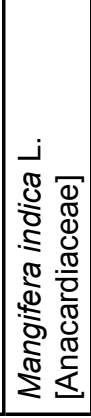 & 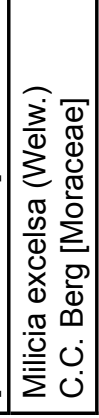 & 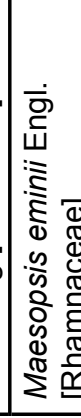 & 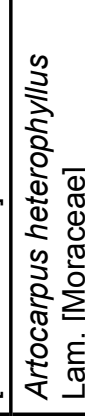 & 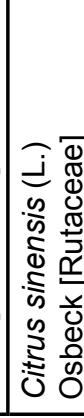 & 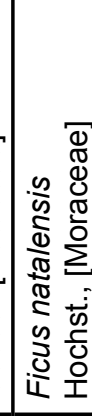 & 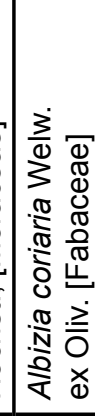 & 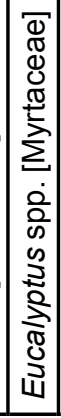 & 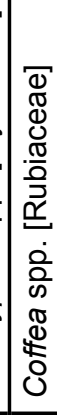 & 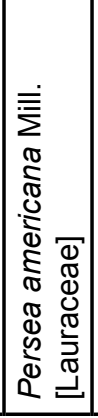 & 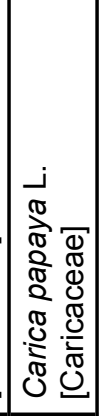 & 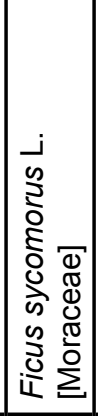 & 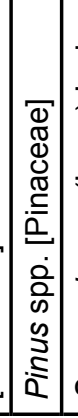 & 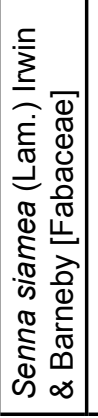 & 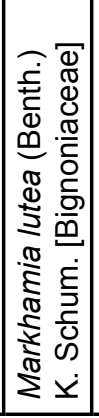 & 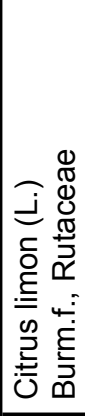 \\
\hline
\end{tabular}




\begin{tabular}{|c|c|c|c|c|c|c|c|c|c|c|c|c|c|c|}
\hline$\therefore$ & $\begin{array}{l}\dot{\theta} \\
\stackrel{\sigma}{\sigma}\end{array}$ & $\begin{array}{l}\infty \\
\infty \\
\infty\end{array}$ & $\left.\right|_{\infty} ^{+}$ & ${ }_{\infty}^{+}$ & $\stackrel{\leftrightarrow}{r}$ & $\check{r}$ & $\hat{\theta}$ & $\hat{\theta}$ & $\hat{\theta}$ & مُ & 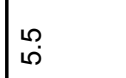 & $\stackrel{\leftrightarrow}{+}$ & $\underset{\sim}{\stackrel{*}{*}}$ & $\stackrel{n}{i}$ \\
\hline Total & প্ল & $\bar{N}$ & i & ని & $\stackrel{\infty}{\sim}$ & $\approx$ & 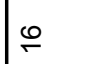 & $\div$ & $\div$ & m & $\underline{m}$ & $=$ & 은 & 0 \\
\hline \multicolumn{15}{|l|}{ Demarcating land } \\
\hline \multicolumn{15}{|l|}{ Mosquito repellant } \\
\hline Making soap & & & & & & & & - & & & & & & \\
\hline \multicolumn{15}{|l|}{ Bee keeping } \\
\hline Water retention & & & & - & & & - & & & & & & & \\
\hline Fencing & & & & & & & & & & & & - & & \\
\hline Soil fertility & & & & - & & & & & & & & & & \\
\hline Rubber & & & - & & & N & & & & & & & & \\
\hline \multicolumn{15}{|l|}{ Rain formation } \\
\hline Beautify compound & & & & & & & & & & & - & - & & \\
\hline Intercropping & & & & - & & & & & & & & & & \\
\hline Wind breaker & & & - & & & & & & & & & - & - & - \\
\hline Construction & & & & & & - & - & & & & & & & $\sim$ \\
\hline Charcoal & & & $\sim$ & & & - & N & & & $\Lambda$ & $\infty$ & & N & - \\
\hline Poles & & & - & & & $\sim$ & - & & & & - & & m & \\
\hline Medicine & - & n & $N$ & & $\theta$ & & N & $F$ & & & & & & - \\
\hline \multicolumn{15}{|l|}{ Fodder } \\
\hline Bark cloth & & & & - & & & & & & & & & & \\
\hline Income & & & & & & $\sim$ & & - & & & & & & \\
\hline Shade & & & - & 0 & - & - & $\sim$ & - & - & $\sim$ & & $\mathbb{N}$ & - & \\
\hline Firewood & & - & $\cong$ & $m$ & - & 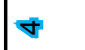 & $m$ & & - & $\theta$ & $m$ & - & $m$ & - \\
\hline Timber & & - & & $N$ & $\sim$ & ष & $\theta$ & & o & & & & & \\
\hline Edible fruit & $\infty$ & $F$ & & & 운 & & & $\sim$ & 울 & & & & & \\
\hline 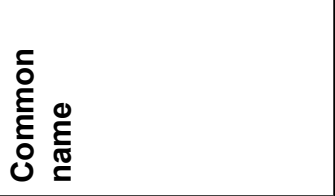 & 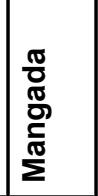 & $\begin{array}{l}\frac{\pi}{8} \\
\frac{0}{\pi} \\
\frac{0}{\pi} \\
\sum\end{array}$ & 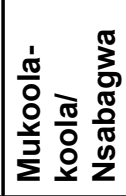 & 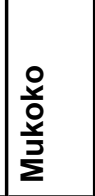 & 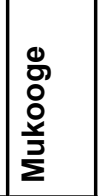 & $\stackrel{\pi}{\Xi}$ & 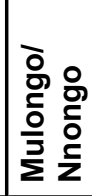 & 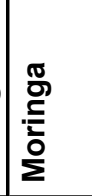 & 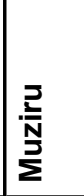 & 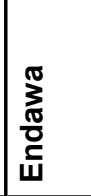 & 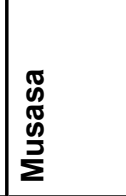 & 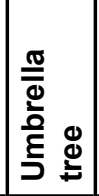 & 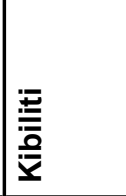 & 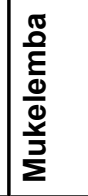 \\
\hline 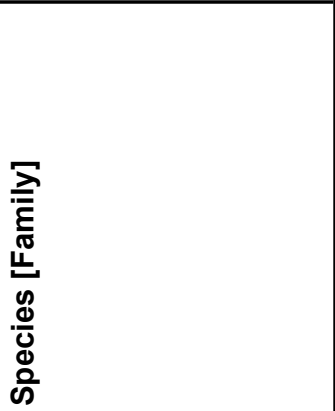 & 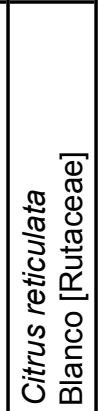 & 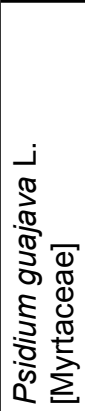 & 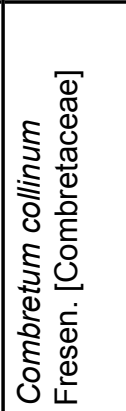 & 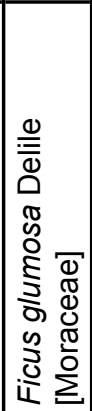 & 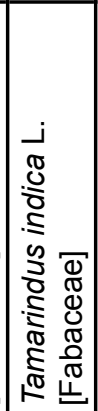 & 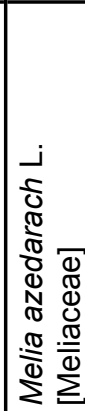 & 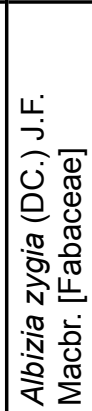 & 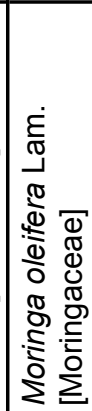 & 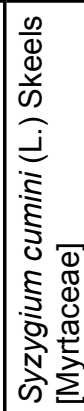 & 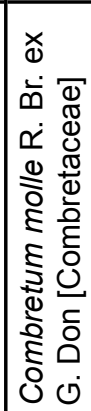 & 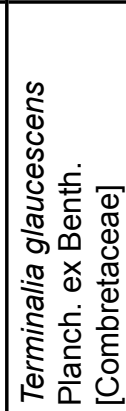 & 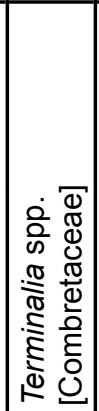 & 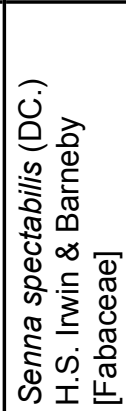 & 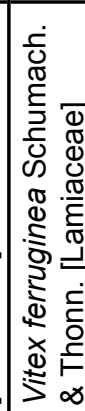 \\
\hline
\end{tabular}


Tabuti - Important Woody Plant Species, their Management and Conservation 281 Status in Balawoli Sub-county, Uganda

\begin{tabular}{|c|c|c|c|c|c|c|c|c|c|c|c|c|c|c|c|}
\hline ๙ & $\bar{i}$ & $\bar{i}$ & $\bar{i}$ & $\bar{i}$ & 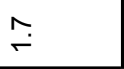 & $\stackrel{\sim}{\sim}$ & $\stackrel{\imath}{\sim}$ & $\stackrel{m}{\sim}$ & $\stackrel{m}{\sim}$ & $\stackrel{m}{\sim}$ & $\stackrel{m}{\sim}$ & $\stackrel{m}{-}$ & $\stackrel{m}{\sim}$ & $\stackrel{\infty}{0}$ & $\stackrel{\infty}{\circ}$ \\
\hline Total & 10 & 10 & م & 10 & $\nabla$ & $\nabla$ & $\nabla$ & $m$ & $m$ & $m$ & $m$ & $m$ & $m$ & $\sim$ & $\sim$ \\
\hline \multicolumn{16}{|l|}{ Demarcating land } \\
\hline \multicolumn{16}{|l|}{ Mosquito repellant } \\
\hline \multicolumn{16}{|l|}{ Making soap } \\
\hline \multicolumn{16}{|l|}{ Bee keeping } \\
\hline \multicolumn{16}{|l|}{ Water retention } \\
\hline Fencing & & & & & & & & & & & & & - & & \\
\hline Soil fertility & & & & & & & & & & - & & & & & \\
\hline \multicolumn{16}{|l|}{ Rubber } \\
\hline \multicolumn{16}{|l|}{ Rain formation } \\
\hline Beautify compound & & & & & & & & & & & & & - & & \\
\hline \multicolumn{16}{|l|}{ Intercropping } \\
\hline Wind breaker & & & - & & & & & & & & & & & & \\
\hline Construction & & & & & $\sim$ & & & & & & & & & & \\
\hline Charcoal & & & & - & & & & & $r$ & & & & & - & \\
\hline \multicolumn{16}{|l|}{ Poles } \\
\hline Medicine & $\nabla$ & & & - & $\sim$ & & & - & - & & - & & & & \\
\hline Fodder & & & & & & & & & & $\sim$ & & & & & \\
\hline \multicolumn{16}{|l|}{ Bark cloth } \\
\hline \multicolumn{16}{|l|}{ Income } \\
\hline Shade & & & $\nabla$ & & & & & & & & & - & & & \\
\hline Firewood & - & - & & $m$ & & & & $\sim$ & - & & - & - & & - & \\
\hline Timber & & - & & & & $\nabla$ & & & & & & & - & & \\
\hline Edible fruit & & $m$ & & & & & $\checkmark$ & & & & - & & & & $\sim$ \\
\hline 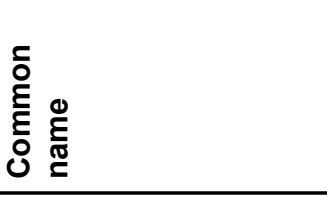 & 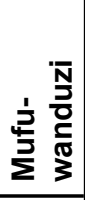 & $\begin{array}{l}\frac{2}{1} \\
\frac{1}{1} \\
\frac{0}{2} \\
\sum\end{array}$ & 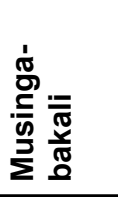 & $\stackrel{\text { }}{\stackrel{N}{2}}$ & 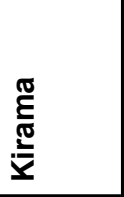 & $\begin{array}{c}\frac{\pi}{3} \\
\frac{2}{3} \\
0\end{array}$ & 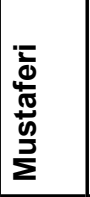 & 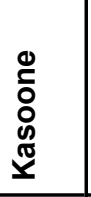 & 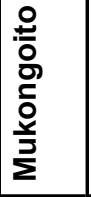 & 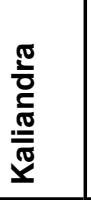 & $\begin{array}{l}\text { N } \\
\text { N } \\
\text { C } \\
\\
\\
\Sigma\end{array}$ & 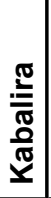 & 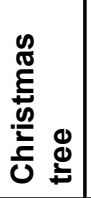 & 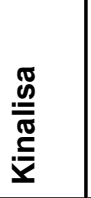 & $\begin{array}{l}\text { ठ̊ } \\
\text { ठ } \\
0\end{array}$ \\
\hline 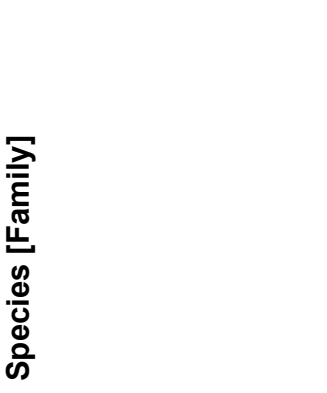 & 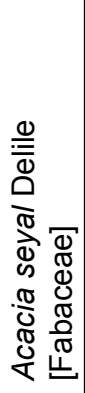 & 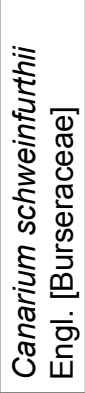 & 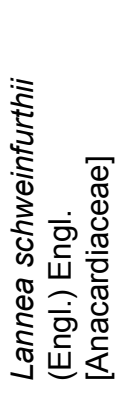 & 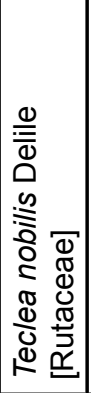 & 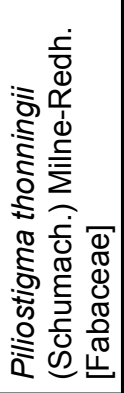 & 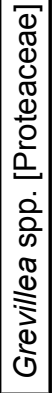 & 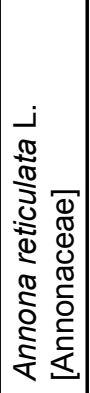 & 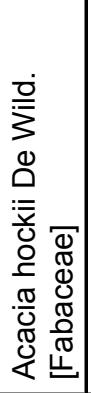 & 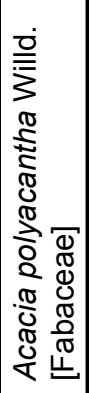 & 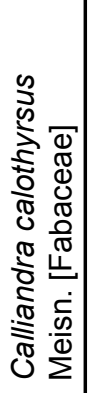 & 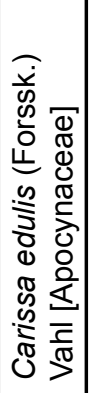 & 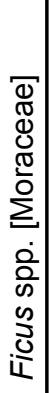 & 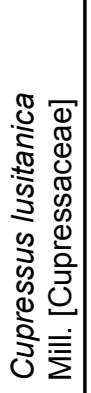 & 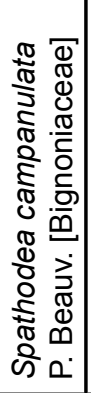 & 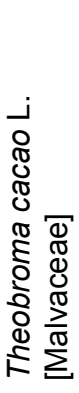 \\
\hline
\end{tabular}




\begin{tabular}{|c|c|c|c|c|c|c|c|c|c|c|c|c|c|c|c|}
\hline$\circ$ & $\begin{array}{l}\infty \\
0 \\
0\end{array}$ & $\begin{array}{l}\infty \\
0 \\
0\end{array}$ & $\begin{array}{l}\infty \\
0 \\
0\end{array}$ & $\begin{array}{l}\infty \\
0 \\
0\end{array}$ & ¿ & : & ث: & 官 & $\stackrel{\Delta}{\circ}$ & ナ. & 茴 & 官 & ث̊. & : & $\stackrel{\Delta}{0}$ \\
\hline Total & N & N & $N$ & N & - & - & - & - & - & - & - & - & - & - & - \\
\hline Demarcating land & & & & & & & & & & & & - & & & \\
\hline Mosquito repellant & & & & & & & & & & & & & & & \\
\hline Making soap & & & & & & & & & & & & & & & \\
\hline Bee keeping & & & & & & & & & & & & & & & \\
\hline Water retention & & & & & & & & & & & & & & & \\
\hline Fencing & & & & & & & & & & & & & & & - \\
\hline Soil fertility & & & & & & & & & & & & & & & \\
\hline Rubber & & & & & & & & & & & & & & & \\
\hline Rain formation & & & & & & & & & & & & & & & \\
\hline Beautify compound & $\sim$ & & & & & & & & & & & & & & \\
\hline Intercropping & & & & & & & & & & & & & & & \\
\hline Wind breaker & & & & & & & & & & & & & & & \\
\hline Construction & & & & & & & & & & & & & & & \\
\hline Charcoal & & & - & & & & & & & & & & & & \\
\hline Poles & & & & & & & & & & & & & & & \\
\hline Medicine & & $\sim$ & & & & & & & - & & & & & & \\
\hline Fodder & & & & & & & & & & & & & & & \\
\hline Bark cloth & & & & & & & & & & & & & & & \\
\hline Income & & & & & & & & & & & & & & & \\
\hline Shade & & & & - & & & & & & & - & & - & & \\
\hline Firewood & & & - & & - & - & & & & & & & & - & \\
\hline Timber & & & & - & & & - & - & & & & & & & \\
\hline Edible fruit & & & & & & & & & & - & & & & & \\
\hline 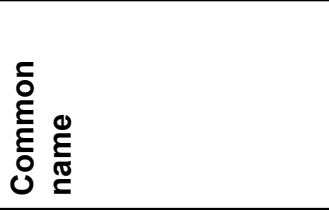 & 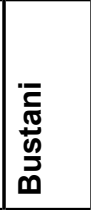 & 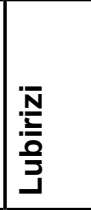 & 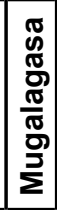 & 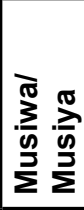 & $\sum_{\Sigma}^{\infty}$ & 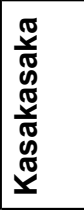 & 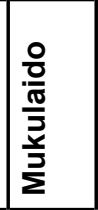 & 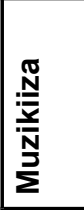 & 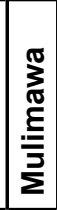 & 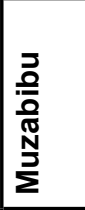 & $\begin{array}{l}\frac{2}{\bar{z}} \\
\frac{1}{3} \\
\frac{x}{5} \\
\underline{\Sigma}\end{array}$ & 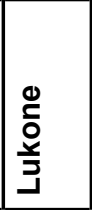 & 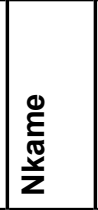 & 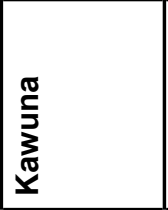 & \begin{tabular}{|l}
$\frac{0}{3}$ \\
0 \\
0 \\
$\underline{\underline{3}}$ \\
$\underline{\underline{z}}$
\end{tabular} \\
\hline 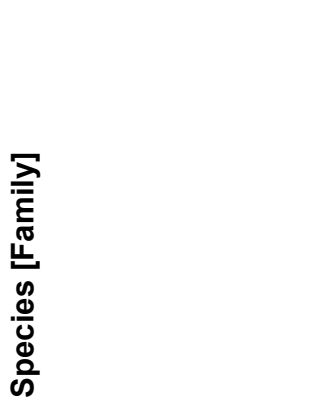 & 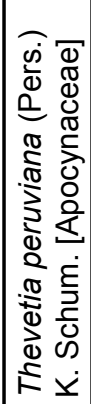 & 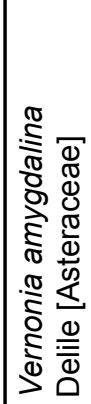 & 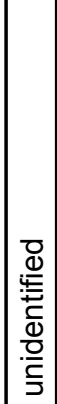 & 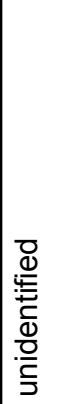 & 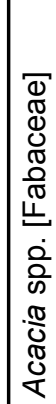 & 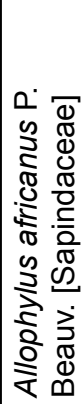 & 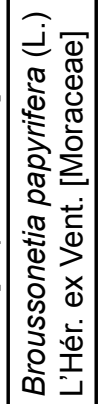 & 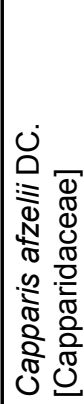 & 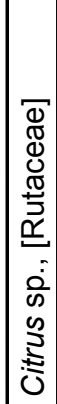 & 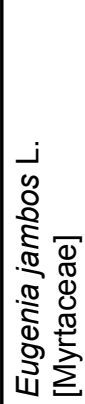 & 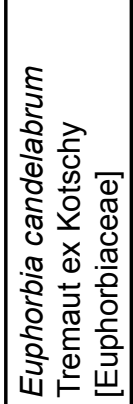 & 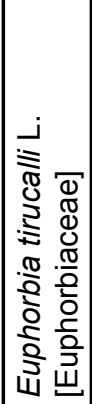 & 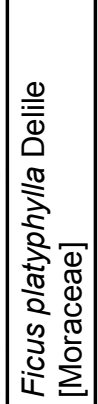 & 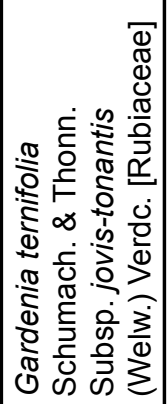 & 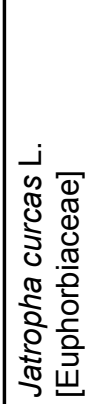 \\
\hline
\end{tabular}


Tabuti - Important Woody Plant Species, their Management and Conservation 283 Status in Balawoli Sub-county, Uganda

\begin{tabular}{|c|c|c|c|c|c|c|c|c|}
\hline$\therefore$ & ¿̊. & ¿̊. & ¿̊. & ¿̊. & ¿̊. & ¿̊. & ¿̊. & ¿̊. \\
\hline Total & - & - & - & - & - & - & - & - \\
\hline \multicolumn{9}{|l|}{ Demarcating land } \\
\hline \multicolumn{9}{|l|}{ Mosquito repellant } \\
\hline \multicolumn{9}{|l|}{ Making soap } \\
\hline \multicolumn{9}{|l|}{ Bee keeping } \\
\hline \multicolumn{9}{|l|}{ Water retention } \\
\hline \multicolumn{9}{|l|}{ Fencing } \\
\hline \multicolumn{9}{|l|}{ Soil fertility } \\
\hline \multicolumn{9}{|l|}{ Rubber } \\
\hline \multicolumn{9}{|l|}{ Rain formation } \\
\hline \multicolumn{9}{|l|}{ Beautify compound } \\
\hline \multicolumn{9}{|l|}{ Intercropping } \\
\hline \multicolumn{9}{|l|}{ Wind breaker } \\
\hline \multicolumn{9}{|l|}{ Construction } \\
\hline Charcoal & & & & - & - & & & \\
\hline \multicolumn{9}{|l|}{ Poles } \\
\hline Medicine & & - & & & & & & - \\
\hline \multicolumn{9}{|l|}{ Fodder } \\
\hline \multicolumn{9}{|l|}{ Bark cloth } \\
\hline \multicolumn{9}{|l|}{ Income } \\
\hline Shade & & & & & & - & & \\
\hline Firewood & - & & & & & & & \\
\hline \multicolumn{9}{|l|}{ Timber } \\
\hline Edible fruit & & & - & & & & - & \\
\hline 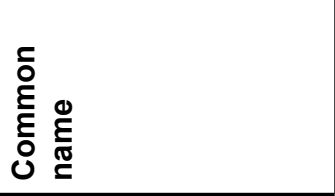 & $\begin{array}{l}\frac{\pi}{0} \\
\frac{5}{\pi} \\
\frac{0}{\pi} \\
\frac{\pi}{\widetilde{T}} \\
\end{array}$ & 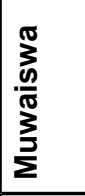 & 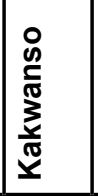 & 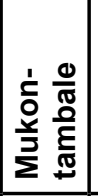 & 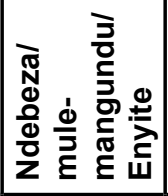 & 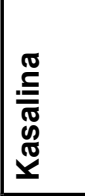 & \begin{tabular}{|l|}
$\frac{3}{\pi}$ \\
3 \\
3 \\
3 \\
\end{tabular} & 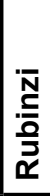 \\
\hline 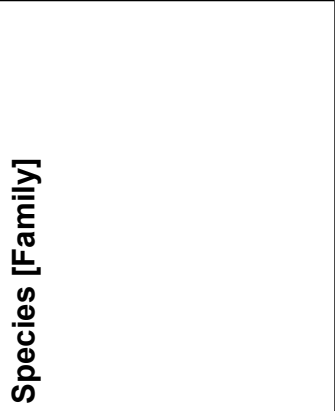 & 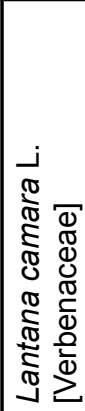 & 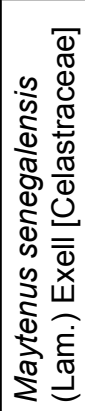 & 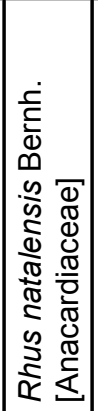 & 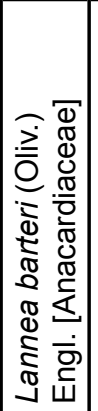 & 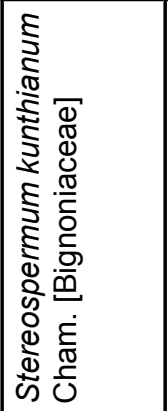 & 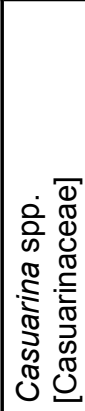 & 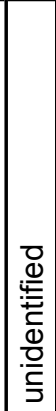 & 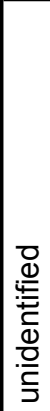 \\
\hline
\end{tabular}


Appendix 2. Marketable species or products and clients in Balawoli Sub-county, Kamuli District, Uganda.

\begin{tabular}{|c|c|c|c|c|}
\hline Species/product & Middlemen & Fellow farmers & Total & $\%$ \\
\hline Citrus sinensis (L.) Osbeck & 44 & 6 & 50 & 19.6 \\
\hline Artocarpus heterophyllus Lam. & 28 & 13 & 41 & 16.1 \\
\hline Mangifera indica L. & 29 & 6 & 35 & 13.7 \\
\hline Coffea spp. & 24 & 1 & 25 & 9.8 \\
\hline Milicia excelsa (Welw.) C.C. Berg & 7 & 9 & 16 & 6.3 \\
\hline Citrus reticulata Blanco & 11 & & 11 & 4.3 \\
\hline Maesopsis eminii Engl. & 4 & 6 & 10 & 3.9 \\
\hline Persea americana Mill. & 7 & 2 & 9 & 3.5 \\
\hline Citrus limon (L.) Osbeck & 6 & 3 & 9 & 3.5 \\
\hline Ficus natalensis Hochst. & 2 & 3 & 5 & 2.0 \\
\hline Carica papaya L. & 2 & 3 & 5 & 2.0 \\
\hline Markhamia lutea (Benth.) K. Schum. & 0 & 4 & 4 & 1.6 \\
\hline Eucalyptus spp. & 1 & 2 & 3 & 1.2 \\
\hline Terminalia glaucescens Planch. ex Benth. & 1 & 1 & 2 & 0.8 \\
\hline Teclea nobilis Delile & 2 & & 2 & 0.8 \\
\hline Albizia coriaria Welw. ex Oliv. & & 2 & 2 & 0.8 \\
\hline Tamarindus indica L. & 1 & & 1 & 0.4 \\
\hline Senna siamea (Lam.) H.S. Irwin \& Barneby & & 1 & 1 & 0.4 \\
\hline Moringa oleifera Lam. & 1 & & 1 & 0.4 \\
\hline Ficus sycomorus L. & 1 & & 1 & 0.4 \\
\hline Combretum molle R. Br. ex G. Don & 1 & & 1 & 0.4 \\
\hline Combretum collinum Fresen. & 1 & & 1 & 0.4 \\
\hline Albizia zygia (DC.) J.F. Macbr. & 1 & & 1 & 0.4 \\
\hline Pinus spp. & & 1 & 1 & 0.4 \\
\hline Timber & 1 & 6 & 7 & 2.7 \\
\hline Medicine & & 1 & 1 & 0.4 \\
\hline Furniture & & 1 & 1 & 0.4 \\
\hline Firewood & & 2 & 2 & 0.8 \\
\hline Charcoal & 1 & 3 & 4 & 1.6 \\
\hline
\end{tabular}


Tabuti - Important Woody Plant Species, their Management and Conservation 285 Status in Balawoli Sub-county, Uganda

Appendix 3. Woody species reportedly maintained by farmers and their location on farms in Balawoli Sub-county, Kamuli District, Uganda.

\begin{tabular}{|c|c|c|c|c|c|c|}
\hline \multirow[t]{2}{*}{ Species } & \multicolumn{5}{|c|}{ Where found } & \multirow[t]{2}{*}{ Tota } \\
\hline & Garden & Courtyard & Backyard & Hedge & Everywhere & \\
\hline Maesopsis eminii Engl. & 85 & 20 & 16 & 12 & & 133 \\
\hline Mangifera indica L. & 64 & 34 & 19 & 4 & 1 & 122 \\
\hline $\begin{array}{l}\text { Milicia excelsa (Welw.) } \\
\text { C.C. Berg }\end{array}$ & 95 & 14 & 7 & & & 116 \\
\hline Artocarpus heterophyllus Lam. & 64 & 29 & 17 & 2 & & 112 \\
\hline Citrus aurantium L. & 45 & 30 & 23 & 1 & 1 & 100 \\
\hline Ficus natalensis Hochst. & 71 & 10 & 7 & 2 & & 90 \\
\hline Albizia coriaria Welw. ex Oliv. & 59 & 6 & 3 & & & 68 \\
\hline Coffea spp. & 42 & 4 & 8 & & & 54 \\
\hline Carica papaya L. & 16 & 13 & 11 & & & 40 \\
\hline Persea americana Mill. & 12 & 6 & 9 & & & 27 \\
\hline $\begin{array}{l}\text { Markhamia lutea (Benth.) } \\
\text { K. Schum. }\end{array}$ & 22 & 4 & 2 & 2 & & 30 \\
\hline Citrus reticulata Blanco & 9 & 11 & 1 & & 1 & 22 \\
\hline Ficus sycomorus L. & 20 & 1 & 1 & & & 22 \\
\hline $\begin{array}{l}\text { Senna siamea (Lam.) } \\
\text { H.S. Irwin \& Barneby }\end{array}$ & 12 & 7 & 2 & 1 & & 22 \\
\hline Citrus limon (L.) Osbeck & 10 & 6 & 2 & & & 18 \\
\hline Pinus spp. & 15 & & 1 & & & 16 \\
\hline Eucalyptus spp. & 9 & 2 & & 3 & & 14 \\
\hline Ficus glumosa Delile & 10 & & 3 & & & 13 \\
\hline Melia azedarach L. & 8 & 2 & 2 & & & 12 \\
\hline Tamarindus indica L. & 7 & 2 & 1 & 1 & & 11 \\
\hline $\begin{array}{l}\text { Lannea schweinfurthii } \\
\text { (Engl.) Engl. }\end{array}$ & 4 & 2 & 1 & & & 7 \\
\hline Moringa oleifera Lam. & 3 & 3 & 3 & & & 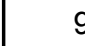 \\
\hline Albizia zygia (DC.) J.F. Macbr. & 6 & 1 & & & & 7 \\
\hline Combretum collinum Fresen. & 6 & 1 & & & & 7 \\
\hline $\begin{array}{l}\text { Combretum molle R. Br. } \\
\text { ex G. Don }\end{array}$ & 4 & 2 & & & & 6 \\
\hline $\begin{array}{l}\text { Terminalia glaucescens } \\
\text { Planch. ex Benth. }\end{array}$ & 6 & & & & & 6 \\
\hline Psidium guajava L. & 7 & & & & & 7 \\
\hline $\begin{array}{l}\text { Vitex ferruginea } \\
\text { Schumach. \& Thonn. }\end{array}$ & 4 & 1 & & & & 5 \\
\hline $\begin{array}{l}\text { Senna spectabilis (DC.) } \\
\text { H.S. Irwin \& Barneby }\end{array}$ & 1 & 1 & 1 & & & 3 \\
\hline Acacia polyacantha Willd. & 2 & & 1 & & & 3 \\
\hline Grevillea spp. & & 1 & 2 & & & 3 \\
\hline Syzygium cumini (L.) Skeels & 3 & & & & & 3 \\
\hline Terminalia spp. & 1 & 2 & & & & 3 \\
\hline Thevetia peruviana K.Schum & & & & 3 & & 3 \\
\hline
\end{tabular}




\begin{tabular}{|l|c|c|c|c|r|r|}
\hline \multirow{2}{*}{ Species } & \multicolumn{3}{|c|}{ Where found } & Total \\
\cline { 2 - 6 } & Garden & Courtyard & Backyard & Hedge & Everywhere & \\
\hline $\begin{array}{l}\text { Gardenia ternifolia Schumach. } \\
\text { \& Thonn. Subsp. jovis-tonantis } \\
\text { (Welw.) Verdc. }\end{array}$ & 2 & & & & & \\
& & & & & & \\
\hline Acacia seyal Delile & & & 1 & & & 1 \\
\hline Allophylus africanus P. Beauv. & 1 & & & & & 1 \\
\hline Anacardium occidentale L. & & 1 & & & & 1 \\
\hline Canarium schweinfurthii Engl. & 1 & & & & & 1 \\
\hline Ficus sp. & 1 & & & & & 1 \\
\hline Ficus vallis-choudae Delile & 1 & & & & & 1 \\
\hline Jatropha curcas L. & & & & & & 1 \\
\hline Lannea barteri (Oliv.) Engl. & 1 & & & & & 1 \\
\hline Manihot glaziovii Müll. Arg. & 1 & & & & & 1 \\
\hline Teclea nobilis Delile & 1 & & & & & 1 \\
\hline Unidentified, Mukomakoma & 2 & & 1 & & & 3 \\
\hline Unidentified, Bandiri & & 1 & & & & 1 \\
\hline Unidentified, Kalongo & & & & 1 & & 1 \\
\hline Unidentified, Mukokowe & 1 & & & & & 1 \\
\hline $\begin{array}{l}\text { Unidentified, Mukoma } \\
\text { mawanga }\end{array}$ & & 1 & & & & 1 \\
\hline Unidentified, Sikamoti & & 1 & & & & 1 \\
\hline Total & $\mathbf{7 3 4}$ & $\mathbf{2 1 9}$ & $\mathbf{1 4 5}$ & $\mathbf{3 3}$ & $\mathbf{3}$ & $\mathbf{1 8 1}$ \\
\hline
\end{tabular}

